$\checkmark$ Research Square

\title{
Using Integrated Assessment Approach to Prioritise Performance Indicators for Sustainable Construction and Development of Secondary Campuses
}

\section{ChaoYang Zhang}

Jimei University

TsungJuang Wang ( $\nabla$ tjwang@mail.ntut.edu.tw )

Jimei University https://orcid.org/0000-0002-9198-7861

Original article

Keywords: analytical hierarchical process, fuzzy delphi method, energy saving, low carbon campus, sustainability indicators

Posted Date: January 22nd, 2021

DOI: https://doi.org/10.21203/rs.3.rs-148683/v1

License: (c) (i) This work is licensed under a Creative Commons Attribution 4.0 International License.

Read Full License 


\title{
Using Integrated Assessment Approach to Prioritise performance indicators for Sustainable construction and development of Secondary campuses
}

\author{
ChaoYang Zhang ${ }^{1}$, TsungJuang Wang ${ }^{1, *}$ \\ 1 College of Arts and Design, JiMei University, Xiamen, Fujian Province, 361021, China; \\ * Correspondence, Distinguished Professor \& Minjiang Scholars
}

\begin{abstract}
:
Background: Sustainable development is a global trend, prompting the development of green school buildings. Green building and low-carbon campus promotion in junior high schools and elementary schools were researched in this study to facilitate improved environmental protection, energy saving, and carbon reduction as well as the construction of green, low-carbon campuses.

Methods: A review of green building certification approvals was used to establish a green campus assessment system with suitable sustainability factors. Relevant indicators were constructed using the Fuzzy Delphi Method and the Analytic Hierarchy Process. Questionnaires were administered to various types of experts regarding the decision sequence for constructing a green, low-carbon campus in junior high schools and elementary schools.

Results: The decision most highly prioritized by all experts was related to lifestyle education and policy management. A healthy campus environment was assigned second place. Energy- and carbon-saving planning and the ecoenvironment were ranked lower. The results provide a reference for architectural planning and implementation, for schools, and for researchers.

Conclusion: The government can use them to inform appropriate policies and to establish priorities and indicator weights for promoting green, low-carbon school campuses. Education resources can thereby be reasonably allocated, green building quality on campuses enhanced, and energy-saving and carbon-saving measures implemented.
\end{abstract}

Keywords: analytical hierarchical process; fuzzy delphi method; energy saving; low carbon campus; sustainability indicators

\section{Background}

Research background: In accordance with the global sustainable development trend, in 2002, Taiwan planned the Challenge 2008-National Development Plan, and the Ministry of Education planned the Sustainable Campus Project with the goal of creating green, sustainable campuses. In 2003, "comfort" and "ecology" were deemed biodiversity indicators and indoor environment indicators. Nine major assessment realms were formed under the four major categories of ecology, energy saving, waste reduction, and health to establish the EEWH system, a new assessment for green buildings in Taiwan. However, in 2003, the system of nine major assessment indicators was updated because the assessment method and index numbers could not reasonably reflect the quality of a green building or effectively increase the relative standards for green buildings. It also failed to provide a reasonable green building reward policy and relevant rewards in professional remuneration, floor area ratio, taxation, and financing [1]. As a result, in 2004, the Ministry of the Interior developed an updated classification assessment method. A five-level assessment method featuring diamond-, gold-, silver-, bronze-, and qualified-level certificates was established and implemented on January 1, 2007. Because the government achieved favorable performance on green building energy saving, water saving, and ecology and environmental protection, it expanded its practice and launched the Eco-city Green Building Promotion Project in 2008 to incorporate 
sustainable cities into Taiwan's green buildings. In 2010, Taiwan incorporated smart green buildings into four major emerging smart industries (i.e., cloud computing, smart electric cars, smart green building, and industrial inventions and patents) and into the Eco-city Green Building Promotion Project. In December 2010, the Smart Green Building Promotion Project was passed, according to which, smart green campuses were to be promoted each year, and the regulation was amended such that new public constructions with a project cost of more than NT\$50 million would be required to apply for a smart building mark. In 2016, the government promoted the Sustainable Smart City-Smart Green Building and Community Promotion Project, striving for increased energy saving and indoor environmental quality as well as reduced environmental impact.

School buildings and campus environments in Taiwan have played critical roles in the promotion of green building as well as energy conservation and carbon reduction in Taiwan. Specifically, junior high schools and elementary schools are the beginning of education; hence, they have a strong weight in promoting energy saving and environmental protection as well as green education. Therefore, topics related to green building and low-carbon campus promotion in junior high schools and elementary schools were explored in this study, with the intended outcomes of improved environmental protection, energy saving, and carbon reduction in schools as well as the construction of an outstanding green, low-carbon campus.

In this study, sustainability factors were identified, and an assessment system suitable for green campus assessment in Taiwan was constructed. This allows competent government authorities to understand and establish appropriate policies and to establish priorities and indicator weights for the promotion of green and low-carbon campuses at schools. Accordingly, a reference can be provided for architects' planning and implementation; for promotion, implementation, and assessment by schools; and for relevant research. Education resources can thus be reasonably allocated, effectively improving green building quality on campus and increasing energy saving and carbon saving.

\section{Methodologies}

Regarding sustainable campuses and green school building planning, Ghent et al. [2] stated that sustainable school planning and design must consider the following factors: energy efficiency, environmental impact, resource protection, and air quality [3-5]. Shih et al. [6] contended that sustainable schools should reduce waste; use materials and resources that can be repaired, renewed, and reused; establish renewable energy; utilize environmental climate features to reduce reliance on energy; construct a healthy and safe learning environment; and connect school education with community resources [7]. AASHE [7] stated that school campus planning characteristics were not limited to education but extended to building foundations, rich ecology, building allocation, healthy and safe learning environments, drinking water and air quality, teachers' and students' quality of life, and the diversity and affordability of buildings. Campus planning considers not only the site and surrounding environment but, more broadly, includes factors such as education, humanities, society, economy, transportation, and environmental protection. Therefore, compared with general business or residential buildings, schools' campus planning and green building design assessment involve more considerations. Yeh et al. [8] studied the green building planning of junior high schools and elementary schools regarding the site and ecoenvironment, and they stated that school sites, compared with those of general buildings, have larger areas, richer ecology, more greenery, and more permeable layers, so they are essential in the urban areas that lack green lands. Arrangment of school buildings is commonly in the form of building groups that separate the stationery and activity zones according to the characteristics of the foundation and natural environment $[1,9]$. During the early period of the planning, the campus life-cycle assessment plan should be considered comprehensively to avoid huge maintenance and repair fees in the future [1,7]. Resources such as flexible space, maintenance and management, durability design, large-area campus sports fields, and idle space generated by social changes must be exploited $[1,10]$. 
The education reform movement has led to many forms of open concepts in the operation of junior high schools and elementary schools. Tang [1] outlined the following five aspects to be considered in sustainable campus planning with green buildings. (1) Emphasize the relationship between school and community, seeking reasonable transparency and openness in opinion exchange and participatory expression. (2) Emphasize the cycle of management of resources and energy. Emphasize resource recycling and reuse, rain water regeneration and reuse, the application of renewable energy, energy-saving design measures, and water-saving and electricity-saving utilities. (3) Emphasize the sustainable management of the construction foundation, including the improvement of the surface soil, multilayer greenery, and planning ponds for scenery or teaching. (4) Value ecoenvironments, including by establishing a field, for education purposes, where fallen leaves and food waste are used as compost or where symbiotic animals are kept. (5) Value healthy building environments, including adaptations for the local natural climate and the use of healthy construction materials. The design of campus space is no longer restricted by fences or rigid concrete buildings. Campuses can be more localized, diverse, green and aesthetic, with a garden-like atmosphere, and humanized. Education methods can be rendered more flexible, more open, and more relevant to daily life. Concretely speaking, schools require environmental policy and action guidelines, environmental action organizations, and community action partners [11]. Students require open and cooperative learning attitudes, critical thinking, and skills to participate in the activities and environmental research surveys conducted by schools and to engage in community affairs [12]. Green school campus building and space allocation is environmentally friendly, safe, and human [7]. Green school campuses feature resource saving, substance cycling, low pollution, and low noise levels [13]. School administration and teachers and students implement promotion of environmentalism on- and off-campus, for example, through teaching that focuses on environmentalism, participation in community cleaning and greening, civil and governmental activities, environmental teaching, expansion of local and outdoor education, establishment of trails for environmental education in community and school, and activities such as immersive teaching and green curriculum development [1].

In 2018, an innovative design company in the United States proposed sustainable schools guidelines, with major design elements including principles such as site and scenery planning and design, utilization of natural light, energy-saving measures for the external shells of buildings, renewable energy systems, high-efficiency lighting and electricity systems, high-efficiency machines and ventilation equipment, environmentally friendly buildings, good indoor air quality, water resources, resource cycling and reuse, waste management, green transport, maintenance management, and ecological education. Many studies $[8,12,14,15]$ have asserted that planning principles for green buildings in schools require at least five functions: ecology, technology, education, efficiency, and health. The findings of these studies were in line with those of Huckle [16] and Łaszkiewicz and Sikorska [17] regarding green school space planning principles for improving the overall ecology of the school, learning and participation opportunities, and sustainable planning. They were also in line with Feng and Li [18], who stated that green schools emphasize environmental symbiosis, suitable technology, the consideration of natural light and ventilation in design, and a reduction in nonnatural methods. Reused and recycled materials are prevalent among those selected for construction. In the spatial design, teaching and the use of teachers and students are considered, providing a space for teacher-student interaction. These should be directions toward which sustainable campuses may work.

Schools are spaces in which children learn. Compared with for adults, stricter health regulations and safer teaching environments are required for children. Therefore, indoor environment quality, drinking water, air quality, and environmental pollution prevention must be emphasized [19]. Specifically, when the site of a school is selected, environmental pollution problems in the neighborhood should be considered. Moreover, schools can use suitable energy-saving technology or high-efficiency facilities to save energy in combination with appropriate teaching. According to statistics, lighting equipment accounts for the most electricity use in schools in Taiwan. Therefore, energy-saving designs for lighting equipment 
can be implemented, using high-efficiency equipment and monitoring to achieve the goal of energy saving $[7,20]$. Compared with general residential spaces, schools have more teachers and students. Therefore, the management and recycling of resources and everyday waste such as food waste and refuse are more critical [21]. Finally, the major purpose of schools is education. The spaces and facilities at schools not only facilitate education but are also designed for teacher-student interaction and connection with local culture and communities. Therefore, schools have ecoenvironmental requirements such as green buildings, technology, and renewable energy $[18,22]$. Integrating environmental education resources into education is key to the proactive creation of sustainable campuses.

\section{Research Content, Method, and Procedure}

\section{Research Method}

This study performed a literature review and employed two analytical methods, namely the Fuzzy Delphi method and the analytic hierarchy process (AHP), to design a three-stage framework and acquire research results. In the first stage, we collected literature related to green school buildings, low-carbon schools, and sustainable campuses. The literature review and analysis were conducted to draft the assessment factors and hierarchy framework of the Application Sequence for Promoting Green, Low-carbon Campuses in Junior High Schools and Elementary Schools in Taiwan. The second stage involved the Fuzzy Delphi method. We first designed a questionnaire by using the assessment factors and hierarchy framework. A team composed of experts from the industry, government, and academia was formed. After the questionnaire was administered and retrieved, expert opinions were compiled to calculate double triangular fuzzy numbers. Expert opinions were then reviewed to establish whether a consensus was reached. Assessment factors for which no consensus was reached were resurveyed or deleted. Subsequently, thresholds were established for screening assessment factors to establish assessment factors and a hierarchy framework. The third stage was AHP. An AHP questionnaire was designed. A team of experts from the government and academia was formed. After the questionnaire survey was implemented and the results retrieved, experts' opinions were used to establish a pairwise comparison matrix and calculate eigenvalues. A consistency test was implemented to verify whether the analysis results were logical. If the critical ratio $(C R)$ value $\leq 0.1$, then the analysis results were reasonable and passed. If the $C R$ value $>0.1$, the results did not pass. The questionnaire survey was repeated, or items in the expert questionnaire were deleted. The assessment factors and overall assessment system indicator weights of the Application Sequence for Promoting Green, Low-carbon Campuses in Junior High Schools and Elementary Schools in Taiwan were thereby obtained. After research and analysis, they could be used as the basis for the Application Sequence for Promoting Green, Low-carbon Campuses in Junior High Schools and Elementary Schools in Taiwan.

\section{Preliminary Test for the Raw Assessment Factors in the Expert Questionnaire}

To discuss factors involved in promoting green, low-carbon campuses in junior high schools and elementary schools in Taiwan, in the literature review section, literature on low-carbon schools, green school buildings and assessment systems, sustainable campuses, and green schools in Taiwan and abroad was collected as the basis for research. The assessment factors and framework selection were based on the principles of objectivity, scientificalness, predictability, and comparableness [23]. Relevant literature on green low-carbon campuses was examined. We preliminarily organized 62 assessment factors for promoting green, low-carbon campuses (Table 1) into the following six major categories:

1. Sustainable site planning.

2. Campus maintenance and lifespan management.

3. Life and learning.

4. Ecological environment.

5. Energy and carbon-saving design, planning, and application. 
6. Healthy campus environment.

Table 1. Preliminary assessment factors.

\begin{tabular}{|c|c|c|c|}
\hline Aspect & Assessment Factor & Aspect & Assessment Factor \\
\hline \multirow{10}{*}{$\begin{array}{l}\text { Sustainable site } \\
\text { planning }\end{array}$} & School location selection & Ecological & Old tree protection \\
\hline & Overall demand plan & environment & $\begin{array}{l}\text { Reduce building coverage and } \\
\text { underground excavation }\end{array}$ \\
\hline & Regional environment assessment & & $\begin{array}{c}\text { Facilities for flood prevention, } \\
\text { water retention, and water storage }\end{array}$ \\
\hline & Building economy of scale & & Water permeable area \\
\hline & Green transport & & Soil conservation \\
\hline & Transportation convenience & $\begin{array}{c}\text { Energy and } \\
\text { carbon-saving }\end{array}$ & $\begin{array}{c}\text { Energy-saving building shell } \\
\text { design }\end{array}$ \\
\hline & $\begin{array}{l}\text { Environmentally friendly school } \\
\text { building planning }\end{array}$ & $\begin{array}{l}\text { design, } \\
\text { planning, and }\end{array}$ & Air conditioning energy saving \\
\hline & Artifact preservation & application & $\begin{array}{c}\text { Energy-saving lighting equipment } \\
\text { and systems }\end{array}$ \\
\hline & Infrastructure provision & & $\begin{array}{c}\text { Manageable green renewable } \\
\text { energy }\end{array}$ \\
\hline & $\begin{array}{l}\text { Participation of teachers, students, } \\
\text { and members of the public }\end{array}$ & & $\begin{array}{c}\text { Power-saving monitoring } \\
\text { management system }\end{array}$ \\
\hline \multirow{3}{*}{$\begin{array}{l}\text { Campus } \\
\text { maintenance } \\
\text { and lifespan } \\
\text { management }\end{array}$} & $\begin{array}{l}\text { Life-cycle assessment of the } \\
\text { buildings on campus }\end{array}$ & & $\begin{array}{c}\text { Adequately lightweight building } \\
\text { materials }\end{array}$ \\
\hline & $\begin{array}{l}\text { Information smart management } \\
\text { platform }\end{array}$ & & Green procurement \\
\hline & $\begin{array}{l}\text { Lifespan extension plan for facility } \\
\text { maintenance management }\end{array}$ & & $\begin{array}{l}\text { Convenient design for building } \\
\text { facility maintenance }\end{array}$ \\
\hline \multirow{7}{*}{$\begin{array}{l}\text { Life and } \\
\text { learning }\end{array}$} & Creative campus features & & Durable building design \\
\hline & $\begin{array}{l}\text { Campus energy-saving } \\
\text { management policy }\end{array}$ & & Reuse of old campus buildings \\
\hline & $\begin{array}{l}\text { Overall use of green construction } \\
\text { principles in the school and } \\
\text { community }\end{array}$ & & Construction waste reduction \\
\hline & $\begin{array}{l}\text { Promotion of green low-carbon } \\
\text { courses and education }\end{array}$ & & Resource reuse \\
\hline & $\begin{array}{l}\text { Green building demonstration and } \\
\text { explanation }\end{array}$ & & Construction pollution prevention \\
\hline & $\begin{array}{l}\text { Friendly digital environment and } \\
\text { learning }\end{array}$ & $\begin{array}{l}\text { Healthy } \\
\text { campus }\end{array}$ & $\begin{array}{c}\text { Soundproof classroom } \\
\text { environment }\end{array}$ \\
\hline & $\begin{array}{c}\text { Media on campus environmental } \\
\text { protection }\end{array}$ & environment & $\begin{array}{l}\text { Indoor lighting and illumination } \\
\text { quality }\end{array}$ \\
\hline \multirow[t]{7}{*}{$\begin{array}{c}\text { Ecological } \\
\text { environment }\end{array}$} & $\begin{array}{c}\text { Maintenance of favorable campus } \\
\text { ecology and restriction of } \\
\text { development }\end{array}$ & & Adequate ventilation \\
\hline & Ecology restoration & & $\begin{array}{l}\text { Prevention of vibrations and } \\
\text { electromagnetic waves }\end{array}$ \\
\hline & Land restoration & & $\begin{array}{c}\text { Nontoxic green construction } \\
\text { materials }\end{array}$ \\
\hline & $\begin{array}{l}\text { Assessment of the impact of } \\
\text { development on local ecology }\end{array}$ & & $\begin{array}{l}\text { Water-saving facilities and } \\
\text { water-saving management }\end{array}$ \\
\hline & $\begin{array}{c}\text { Small-scale biodiversity } \\
\text { environment }\end{array}$ & & $\begin{array}{c}\text { Water resources recycling and } \\
\text { reuse facilities }\end{array}$ \\
\hline & $\begin{array}{l}\text { Indigenous flora and plant } \\
\text { diversity }\end{array}$ & & Drinking water quality monitoring \\
\hline & Organic biofarming & & Establishment of resource and \\
\hline
\end{tabular}


waste classification and recycling management

Light hazards

Biopond establishment

Ecological multilayer

three-dimensional greening

Extent of campus greening
Sewage processing facilities

Campus air quality monitoring

Refuse disposal centralization and beautification of refuse collection fields

Laboratory safety and toxic substance control and management

\section{Preliminary Assessment Index Framework}

The aforementioned 62 assessment factors for promoting green, low-carbon campus applications were organized, according to importance and relevance, into five major assessment aspects, 14 critical assessment points, and 56 assessment factors. A preliminary green building and low-carbon school application assessment framework and preliminary assessment factors were established for the first-stage Fuzzy Delphi expert questionnaire assessment framework. In the preliminary framework, the major objective layer was Promoting Green Building Low-Carbon School Applications in Junior High Schools and Elementary Schools in Taiwan. Underneath this, the first layer featured the five major aspects: site sustainability, campus ecodiversity, campus energy and carbon-saving, healthy campus environment, and green and low-carbon lifestyles. The second layer featured 14 critical assessment points: site assessment, planning and management, ecological preservation, biodiverse environments, campus greening, foundation water preservation, energy preservation and management, $\mathrm{CO}_{2}$ reduction design, waste reduction, indoor environment quality, water resources and quality, pollution improvement, green administration, and green education. The third layer contained 56 assessment factors.

To obtain the reliability and validity of the questionnaire, a preliminary test was conducted for the reliability and the validity of the Fuzzy Delphi expert questionnaire and the AHP expert questionnaire.

\section{Preliminary Test for the Fuzzy Delphi Expert Questionnaire}

After a literature review, the Application Sequence for Promoting Green, Low-carbon Campuses at Junior High Schools and Elementary Schools in Taiwan assessment framework and preliminary assessment factors were preliminarily established. Subsequently, the draft of the Fuzzy Delphi expert questionnaire was established. Experts were invited by email to conduct the preliminary test for the questionnaire for experts. After suitable adjustments and amendments, the preliminary test on the reliability of the expert questionnaire was conducted. Finally, the official questionnaire survey for experts was conducted. The process of each stage of the preliminary test is subsequently detailed.

1. Preliminary test of the validity of the Fuzzy Delphi expert questionnaire

Seven experts and scholars participated in the preliminary test for the expert questionnaire. This study adopted internal consistency Cronbach's $\alpha$ values to measure reliability. The Cronbach $\alpha$ of each assessment factor should be no less than 0.7. After reliability analysis, we discovered that the Cronbach $\alpha$ value of each factor was between 0.828 and 0.851 , and the overall Cronbach $\alpha$ was 0.839. The Cronbach's $\alpha$ of standardized items was 0.843 , indicating favorable internal consistency and reliability.

2. Preliminary test for the reliability of the Fuzzy Delphi expert questionnaire

Seven experts and scholars participated in the preliminary test for the questionnaire for experts. This study adopted internal consistency Cronbach's $\alpha$ values to measure reliability. The Cronbach's $\alpha$ value of each assessment factor should be no less than 0.7. Reliability analysis revealed that the overall Cronbach's $\alpha$ value was 0.845 (Table 2). The Cronbach's $\alpha$ of standardized items was 0.853. The Cronbach's $\alpha$ value of each item was between 0.836 and 0.855 (Table 3), indicating favorable internal consistency and reliability. The questionnaire exhibited stability, so formal questionnaire implementation could proceed. 
Table 2. Fuzzy Delphi expert questionnaire reliability preliminary test reliability statistics.

\begin{tabular}{ccc}
\hline Cronbach's Alpha & $\begin{array}{c}\text { Cronbach's Alpha Based on } \\
\text { Standardized Items }\end{array}$ & No. of Items \\
\hline .845 & .849 & 56 \\
\hline
\end{tabular}

Table 3. Fuzzy Delphi questionnaire for experts reliability preliminary test overall statistics.

\begin{tabular}{|c|c|c|c|c|}
\hline & $\begin{array}{l}\text { Scale Mean } \\
\text { After } \\
\text { Removal of } \\
\text { Items } \\
\end{array}$ & $\begin{array}{c}\text { Scale Standard } \\
\text { Deviation } \\
\text { After Removal } \\
\text { of Items } \\
\end{array}$ & $\begin{array}{l}\text { Modified } \\
\text { Total Item } \\
\text { Correlation }\end{array}$ & $\begin{array}{c}\text { Cronbach's Alpha } \\
\text { After Removal of } \\
\text { Items }\end{array}$ \\
\hline School location selection & 442.86 & 503.143 & .648 & .838 \\
\hline $\begin{array}{l}\text { Establishment of overall } \\
\text { demand plan and } \\
\text { environmental assessment }\end{array}$ & 442.71 & 533.238 & .201 & .846 \\
\hline $\begin{array}{l}\text { Campus energy-saving } \\
\text { management policy }\end{array}$ & 444.71 & 519.571 & .463 & .842 \\
\hline $\begin{array}{l}\text { Lifespan extension plan for } \\
\text { facility maintenance } \\
\text { management }\end{array}$ & 444.43 & 527.952 & .234 & .845 \\
\hline $\begin{array}{l}\text { Life-cycle assessment of the } \\
\text { buildings on campus }\end{array}$ & 445.00 & 557.000 & -.302 & .855 \\
\hline Building economy of scale & 443.14 & 539.476 & .000 & .850 \\
\hline $\begin{array}{l}\text { Environmentally friendly school } \\
\text { building planning }\end{array}$ & 443.71 & 511.905 & .480 & .841 \\
\hline Create creative campus features & 444.29 & 548.238 & -.188 & .851 \\
\hline $\begin{array}{c}\text { Digital environment and } \\
\text { learning }\end{array}$ & 443.29 & 522.905 & .302 & .844 \\
\hline $\begin{array}{l}\text { Participation of teachers, } \\
\text { students, and the public }\end{array}$ & 443.29 & 540.571 & -.011 & .849 \\
\hline $\begin{array}{l}\text { Overall use of green } \\
\text { construction principles in the } \\
\text { school and the community }\end{array}$ & 443.71 & 496.571 & .684 & .836 \\
\hline Green procurement & 443.71 & 511.905 & .804 & .839 \\
\hline Green transport & 444.14 & 515.810 & .363 & .843 \\
\hline $\begin{array}{l}\text { Media on campus } \\
\text { environmental protection }\end{array}$ & 443.00 & 540.667 & -.008 & .849 \\
\hline $\begin{array}{c}\text { Green low-carbon courses and } \\
\text { education }\end{array}$ & 443.14 & 547.476 & -.183 & .850 \\
\hline $\begin{array}{c}\text { Maintenance of favorable } \\
\text { campus ecology and restriction } \\
\text { of development }\end{array}$ & 443.86 & 545.143 & -.130 & .850 \\
\hline $\begin{array}{c}\text { Repair of ecoenvironmental } \\
\text { damage }\end{array}$ & 443.57 & 519.952 & .455 & .842 \\
\hline Land restoration & 443.14 & 503.810 & .694 & .838 \\
\hline $\begin{array}{l}\text { Assessment of the impact of } \\
\text { development on local ecology }\end{array}$ & 443.29 & 506.238 & .497 & .840 \\
\hline
\end{tabular}




\begin{tabular}{|c|c|c|c|c|}
\hline Biodiversity & 442.71 & 543.238 & -.064 & .850 \\
\hline $\begin{array}{l}\text { Indigenous flora and plant } \\
\text { diversity }\end{array}$ & 444.14 & 536.810 & .097 & .847 \\
\hline Organic biofarming & 444.29 & 502.238 & .687 & .837 \\
\hline Light hazard prevention & 443.86 & 534.476 & .174 & .846 \\
\hline Biopond establishment & 444.29 & 536.571 & .029 & .851 \\
\hline $\begin{array}{l}\text { Ecological multilayer } \\
\text { three-dimensional greening }\end{array}$ & 443.43 & 520.286 & .460 & .842 \\
\hline Extent of campus greening & 444.00 & 522.000 & .446 & .843 \\
\hline Old tree protection & 443.29 & 525.571 & .294 & .845 \\
\hline $\begin{array}{l}\text { Reduce building coverage and } \\
\text { underground excavation }\end{array}$ & 443.71 & 525.238 & .281 & .845 \\
\hline $\begin{array}{c}\text { Facilities for flood prevention, } \\
\text { water retention, and water } \\
\text { storage }\end{array}$ & 442.86 & 505.810 & .599 & .839 \\
\hline Water permeable area & 443.43 & 529.619 & .201 & .846 \\
\hline Soil conservation & 443.00 & 538.000 & .083 & .847 \\
\hline $\begin{array}{c}\text { Energy-saving building shell } \\
\text { design }\end{array}$ & 444.57 & 502.286 & .739 & .837 \\
\hline $\begin{array}{l}\text { Air conditioning and lighting } \\
\text { energy saving }\end{array}$ & 444.43 & 523.286 & .192 & .847 \\
\hline $\begin{array}{l}\text { Energy-saving lighting } \\
\text { equipment and system }\end{array}$ & 444.14 & 553.143 & -.245 & .853 \\
\hline $\begin{array}{c}\text { Manageable green renewable } \\
\text { energy }\end{array}$ & 443.71 & 531.905 & .113 & .848 \\
\hline $\begin{array}{l}\text { Power-saving monitoring } \\
\text { management system }\end{array}$ & 443.71 & 549.905 & -.254 & .851 \\
\hline $\begin{array}{l}\text { Adequately lightweight } \\
\text { building materials }\end{array}$ & 443.00 & 507.667 & .522 & .840 \\
\hline $\begin{array}{l}\text { Convenient design for building } \\
\text { facility maintenance }\end{array}$ & 444.14 & 529.143 & .154 & .847 \\
\hline Durable building design & 445.00 & 517.333 & .404 & .842 \\
\hline Durable building design & 443.86 & 525.810 & .239 & .845 \\
\hline Construction waste reduction & 443.86 & 505.810 & .492 & .840 \\
\hline Reuse of construction materials & 443.14 & 528.476 & .254 & .845 \\
\hline Construction pollution & 443.29 & 524.238 & .277 & .845 \\
\hline Classroom soundproofing & 442.86 & 504.476 & .709 & .838 \\
\hline $\begin{array}{l}\text { School building lighting and } \\
\text { illumination quality }\end{array}$ & 444.43 & 521.286 & .236 & .846 \\
\hline Adequate ventilation & 442.86 & 523.476 & .385 & .843 \\
\hline $\begin{array}{l}\text { Prevention of vibrations and } \\
\text { electromagnetic waves }\end{array}$ & 442.86 & 528.476 & .348 & .844 \\
\hline $\begin{array}{l}\text { Nontoxic green construction } \\
\text { materials }\end{array}$ & 442.57 & 518.286 & .621 & .841 \\
\hline $\begin{array}{l}\text { Establishment of water-saving } \\
\text { facilities and water saving } \\
\text { management }\end{array}$ & 444.71 & 539.905 & .006 & .849 \\
\hline $\begin{array}{l}\text { Establishment of water resource } \\
\text { recycling and reuse facilities }\end{array}$ & 444.57 & 527.619 & .280 & .845 \\
\hline
\end{tabular}




\begin{tabular}{ccccc}
\hline $\begin{array}{c}\text { Drinking water quality } \\
\text { monitoring }\end{array}$ & 443.86 & 538.476 & .060 & .848 \\
$\begin{array}{c}\text { Establishment of resources and } \\
\text { waste classification and } \\
\text { recycling management }\end{array}$ & 442.57 & 521.619 & .526 & .842 \\
$\begin{array}{c}\text { Centralization of refuse disposal } \\
\text { and beautification of refuse } \\
\text { collection fields }\end{array}$ & 442.86 & 509.143 & .538 & .840 \\
$\begin{array}{c}\text { Establishment of sewage } \\
\text { processing facilities }\end{array}$ & 444.00 & 524.667 & .194 & .847 \\
$\begin{array}{c}\text { Campus air quality monitoring } \\
\text { Laboratory safety and toxic } \\
\text { substance control and } \\
\text { management }\end{array}$ & 444.43 & 540.286 & -.007 & .849 \\
$\quad 444.14$ & 530.810 & .102 & .849
\end{tabular}

\section{Results}

\section{Analysis for Results of the Fuzzy Delphi Expert Questionnaire}

The Fuzzy Delphi method in Lei and Huang [24] was referenced in this study. A double triangular fuzzy number approach was adopted to integrate experts' opinions to improve the disadvantage of the Delphi method that it provides only partial information from experts. In addition, the grey zone test was used to more effectively and objectively verify whether experts' opinions converged, thereby identifying whether a consensus was reached. After the Fuzzy Delphi method expert questionnaire was retrieved and experts' opinions organized, the following steps were used: MS Excel 2017 was adopted for statistical analysis. The relevant steps are as follows:

Step 1: Use the Most Conservative Cognition Value, the Most Optimistic Cognition Value, and the Single Value

Expert opinion interval values were calculated. The minimum value, maximum value, and single value in this interval denote the most conservative cognition value, the most optimistic cognition value, and the optimal value of the experts' quantitative scores for the evaluation item, respectively.

Step 2: Remove Extreme Values Outside Two Standard Deviations

For each assessment item $i$, statistical analyses were conducted for the most conservative cognition value and the most optimistic cognition value provided by the experts. After the extreme values outside two standard deviations were removed, the remaining minimum value $C_{L}^{i}$, geometric mean $\quad C_{M}^{i}$, and maximum value $\quad C_{U}^{i}$ of the most conservative cognition values were obtained. Similarly, the minimum value $O_{L}^{i}$, the geometric mean $O_{M}^{i}$, and the maximum value $\quad C O_{U}^{i}$ of the most optimistic cognition values were obtained.

Step 3: Establish Double Triangular Fuzzy Numbers

The triangular fuzzy numbers of the most conservative cognition for each assessment item $i$ ( $\left.\quad C^{i}=\left(\quad C_{L,}^{i}, \quad C_{M}^{i}, \quad C_{U}^{i}\right)\right)$ and of the most optimistic cognition for each assessment item $i$ $\left(O^{i}=\left(\quad O_{L,}^{i} \quad O_{M}^{i}, \quad O_{U}^{i}\right)\right)$ calculated in Step 2 were established.

Step 4: Use the Grey Zone Test Method to Test Whether Consensus is Achieved for Expert Opinions

To evaluate whether consensus was achieved for experts' opinions, this study utilized two triangular fuzzy numbers overlapping (i.e., $\quad C_{U}^{i}>O_{L}^{i}$ ); the grey area in the fuzzy relationship 
$Z^{i}=\quad C_{U}^{i}-O_{L}^{i}$ was larger than the interval between the experts' geometric mean for optimistic cognition and the geometric mean for conservative cognition of the item (i.e.,

$\left.M^{i}=O_{M}^{i}-C_{M}^{i}\right)$. This indicates that no consensus interval exist between experts' opinions and that extreme opinion values assigned by two experts differed greatly from the opinion values of other experts, resulting in a divergence of opinion. Therefore, the assessment items of opinions that did not converge were prevention of vibrations and electromagnetic waves and the centralization of refuse disposal trash and beautify the trash collection fields. Their assessment values were $\mathrm{Mi}_{\mathrm{i}}-\mathrm{Zi}_{\mathrm{i}}<0$ and were therefore deleted.

\section{Step 5: Select a Threshold Value Screening Evaluation Factor}

Threshold values affects the screening numbers of assessment factors. Generally, threshold values are established according to the research objectives of researchers. In this study, to achieve objectivity, the research of Ishikawa et al. [25] was referenced, and based on their research suggestions, threshold values and suggestion values were used for screening assessment factors. The values of assessment factors must be greater than the threshold values and the suggested values. The setting of the threshold value is related to $G_{i}$, which represents the importance of expert consensus. A high $\mathrm{G}_{i}$ value denotes a high level of expert consensus and high importance (Table 4). The threshold of this study was the arithmetic mean of $\mathrm{G}_{i}$, namely the expert consensus value, 6.91. The assessment value was the arithmetic mean of the single-value geometric mean of each evaluation item, and it represented the subjective cognition data provided by experts. In this study, the assessment value was 6.84. Therefore, in this study, assessment factor indicators had to exceed the threshold value 6.91 and the assessment value 6.84 to be selected. A total of 18 assessment factors were deleted: school location selection, building economy of scale, green transport, life-cycle assessment of the buildings on campus, participation of teachers, students, and the public; land restoration; light hazards; biopond establishment, soil conservation, air conditioning energy saving, green procurement, reuse of old campus buildings, construction waste reduction, resource reuse, construction pollution prevention, laboratory safety and toxic substance control and management, digital environment and learning, and media on campus environmental protection. In total, 20 assessment factors were deleted, and 36 assessment factors were selected (64.29\%).

For expert opinions marked with $※$, the two triangular fuzzy numbers have some overlap, and the assessment value $M_{i}-Z_{i} \geq 0$. This means that, although the experts' opinion interval lacked a consensus interval, the differences in their opinions were minimal. The consensus value $\mathrm{Gi}$ was $\mathrm{OL}^{\mathrm{i}}+\left(\mathrm{OM}^{\mathrm{i}}-\mathrm{OL}^{\mathrm{i}}\right){ }^{*}\left(\mathrm{Cu}^{\mathrm{i}}-\right.$ $\left.\mathrm{CM}^{\mathrm{i}}\right) /\left(\left(\mathrm{CU}_{U^{\mathrm{i}}}-\mathrm{CM}^{\mathrm{i}}\right)+\left(\mathrm{OM}^{\mathrm{i}}-\mathrm{OL}^{\mathrm{i}}\right)\right)$.

For expert opinions marked with @, the two triangular fuzzy numbers have some overlap, and the assessment value $\mathrm{Mi}-\mathrm{Zi}<0$. This means that experts' opinions differed greatly, resulting in divergent opinions. The questionnaire survey had to be repeated to for consensus to be achieved. In this study, due to time constraints, such items were deleted.

The regions marked in grey denote assessment criteria that were deleted.

\section{Establishment of the Assessment System and Relevant Analysis}

Preliminarily, 56 assessment factors were drafted for this study. After analysis of the Fuzzy Delphi expert questionnaire responses, we deleted two factors (i.e., prevention of vibrations and electromagnetic waves as well as centralization of refuse disposal facilities and beautification of refuse collection fields) for which no consensus was achieved in the grey zone test. Subsequently, 20 assessment factors (such as school location selection, building economy of scale, and green transport) that did not exceed the threshold value of 6.91 and the assessment value of 6.84 were removed. Figure 1 presents the amended preliminary assessment framework and assessment factors, and the assessment levels and respective factors were used as the implementation basis for 
the next step, the AHP expert questionnaire for the Taiwan green campus assessment mechanism construction research assessment system. 
Table 4. Fuzzy Delphi questionnaire for experts assessment indicator statistics.

\begin{tabular}{|c|c|c|c|c|c|c|c|c|c|c|c|c|}
\hline \multirow[t]{2}{*}{$\begin{array}{l}\text { Assessment } \\
\text { Aspects }\end{array}$} & \multirow[t]{2}{*}{ Critical Assessment Point } & \multirow[t]{2}{*}{ Assessment Factor } & \multirow{2}{*}{$\begin{array}{c}\text { Most } \\
\begin{array}{c}\text { Conservative } \\
\text { Cognition } \\
\text { Value }\end{array} \\
\text { Min } \\
\text { (CLi) }\end{array}$} & \multicolumn{3}{|c|}{$\begin{array}{c}\text { Most Optimistic Cognition } \\
\text { Value }\end{array}$} & \multicolumn{2}{|c|}{ Geometric Mean } & \multicolumn{2}{|c|}{ Assessment Value } & \multirow[t]{2}{*}{$\begin{array}{c}\text { Expert Consensus } \\
\text { Value } \\
\end{array}$} & \multirow{2}{*}{$\begin{array}{l}\text { Expert } \\
\text { Opinion } \\
\text { Interval } \\
\end{array}$} \\
\hline & & & & $\begin{array}{l}\text { Max } \\
\text { (CUi) }\end{array}$ & $\begin{array}{l}\text { Min } \\
\text { (OLi) }\end{array}$ & $\begin{array}{l}\text { Max } \\
\text { (OUi) }\end{array}$ & $\mathrm{CMi}$ & OMi & Single value & $\mathbf{M i}-\mathbf{Z i}$ & & \\
\hline \multirow[t]{8}{*}{ Site sustainability } & \multirow[t]{4}{*}{ Site assessment } & School location selection & 3 & 6 & 5 & 9 & 5.05 & 7.65 & 6.65 & 1.60 & 5.74 & ※ \\
\hline & & $\begin{array}{l}\text { Establishment of overall demand } \\
\text { plan and environmental } \\
\text { assessment }\end{array}$ & 4 & 7 & 7 & 9 & 6.02 & 8.66 & 7.49 & 2.64 & 7.34 & \\
\hline & & Building economy of scale & 2 & 6 & 5 & 10 & 5.25 & 7.02 & 6.54 & 0.77 & 5.73 & ※ \\
\hline & & Green transport & 3 & 7 & 5 & 9 & 4.54 & 7.52 & 6.16 & 0.98 & 6.01 & ※ \\
\hline & \multirow[t]{4}{*}{ Planning management } & $\begin{array}{l}\text { Environmentally friendly school } \\
\text { building planning }\end{array}$ & 5 & 8 & 8 & 10 & 6.04 & 9.03 & 7.37 & 2.99 & 7.54 & \\
\hline & & $\begin{array}{l}\text { Life-cycle assessment of campus } \\
\text { buildings }\end{array}$ & 3 & 8 & 6 & 10 & 5.14 & 7.91 & 6.54 & 0.77 & 6.80 & ※ \\
\hline & & $\begin{array}{l}\text { Lifespan extension plan for } \\
\text { facility maintenance } \\
\text { management }\end{array}$ & 3 & 8 & 7 & 10 & 5.82 & 8.80 & 7.47 & 1.98 & 7.45 & ※ \\
\hline & & $\begin{array}{l}\text { Participation of teachers, } \\
\text { students, and members of the } \\
\text { public }\end{array}$ & 3 & 8 & 6 & 10 & 5.03 & 7.81 & 6.59 & 0.78 & 6.76 & ※ \\
\hline \multirow[t]{11}{*}{$\begin{array}{l}\text { Campus } \\
\text { ecodiversity }\end{array}$} & \multirow[t]{4}{*}{ Ecological environment } & $\begin{array}{l}\text { Maintenance of favorable } \\
\text { campus ecology and restriction } \\
\text { of development }\end{array}$ & 4 & 8 & 7 & 10 & 5.89 & 8.66 & 7.34 & 1.77 & 7.44 & ※ \\
\hline & & Ecology restoration & 3 & 8 & 7 & 10 & 5.07 & 7.90 & 6.30 & 1.83 & 7.23 & * \\
\hline & & Ecology restoration & 2 & 8 & 6 & 10 & 4.89 & 7.68 & 6.42 & 0.79 & 6.70 & ※ \\
\hline & & $\begin{array}{l}\text { Assessment of the impact of } \\
\text { development on local ecology }\end{array}$ & 4 & 8 & 7 & 10 & 5.60 & 8.37 & 6.89 & 1.77 & 7.36 & ※ \\
\hline & \multirow[t]{5}{*}{ Biodiversity } & $\begin{array}{l}\text { Small-scale biodiversity } \\
\text { environment }\end{array}$ & 4 & 8 & 7 & 10 & 5.92 & 8.80 & 7.18 & 1.88 & 7.46 & ※ \\
\hline & & $\begin{array}{l}\text { Indigenous flora and plant } \\
\text { diversity }\end{array}$ & 4 & 8 & 7 & 10 & 6.07 & 8.59 & 7.63 & 1.52 & 7.45 & ※ \\
\hline & & Organic biofarming & 4 & 7 & 7 & 9 & 4.92 & 7.71 & 6.27 & 2.79 & 7.00 & \\
\hline & & Light hazards & 2 & 7 & 6 & 10 & 4.28 & 7.49 & 5.86 & 2.21 & 6.35 & ※ \\
\hline & & Biopond establishment & 2 & 7 & 5 & 10 & 4.50 & 7.46 & 6.47 & 0.96 & 5.99 & * \\
\hline & \multirow[t]{2}{*}{ Campus greening } & $\begin{array}{l}\text { Ecological multilayer } \\
\text { three-dimensional greening }\end{array}$ & 4 & 8 & 7 & 10 & 5.68 & 8.49 & 7.10 & 1.81 & 7.39 & ※ \\
\hline & & Extent of campus greening & 4 & 8 & 7 & 10 & 5.96 & 8.89 & 7.36 & 1.93 & 7.48 & ※ \\
\hline
\end{tabular}




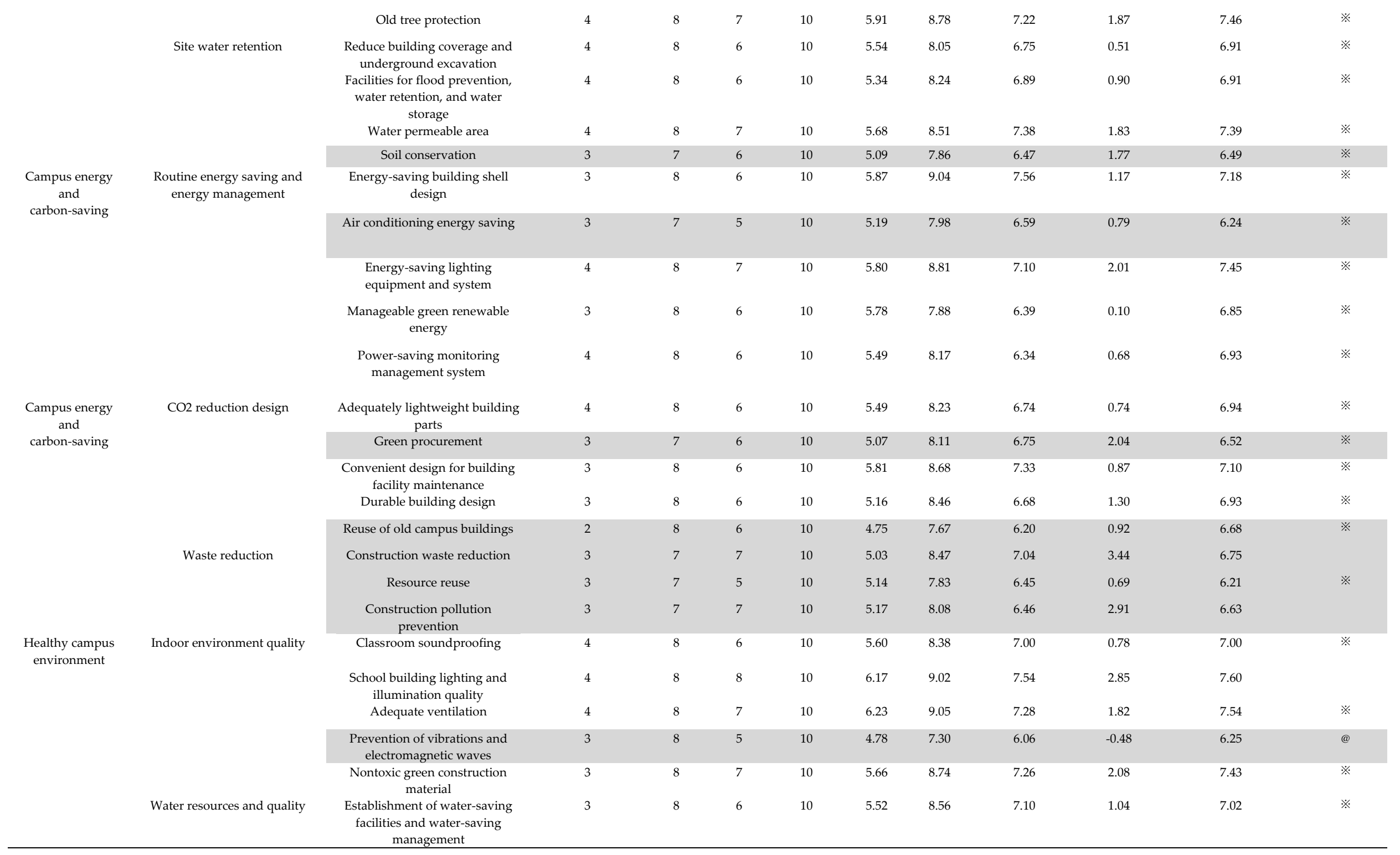




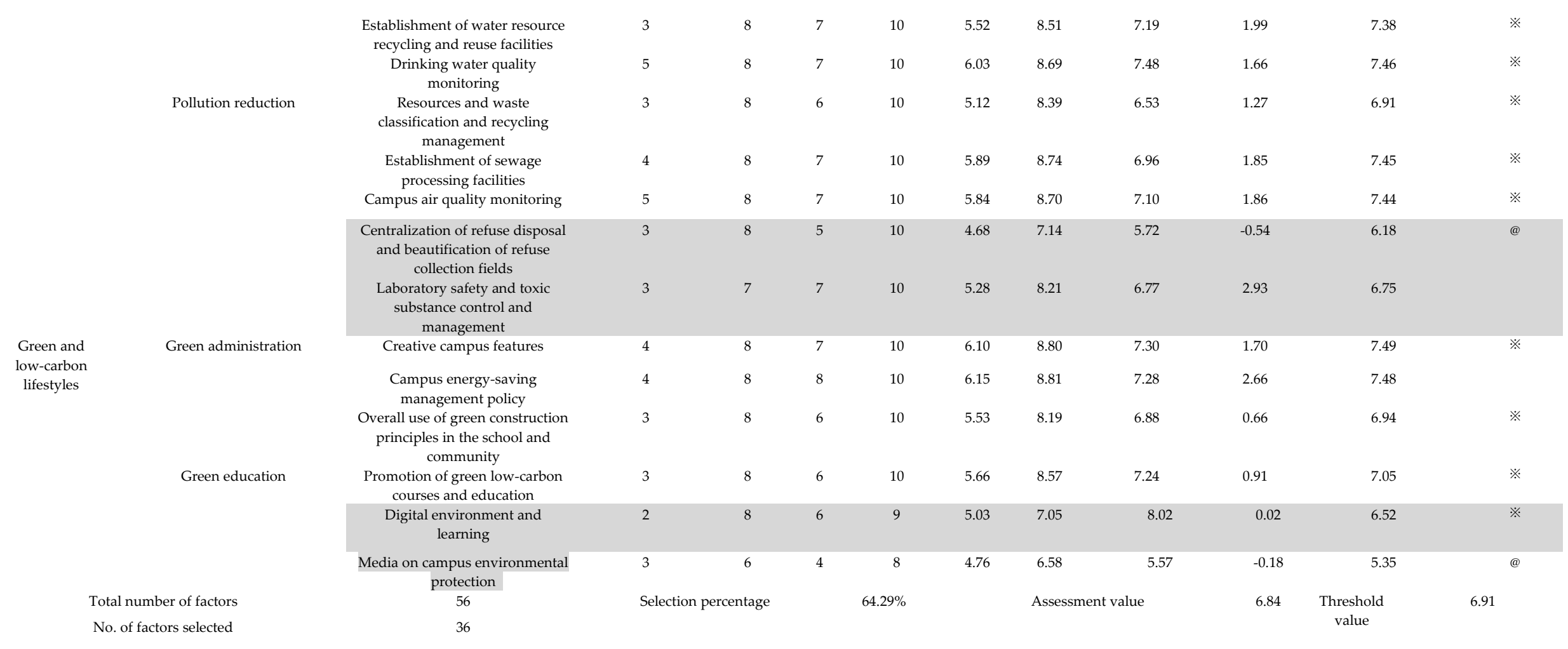




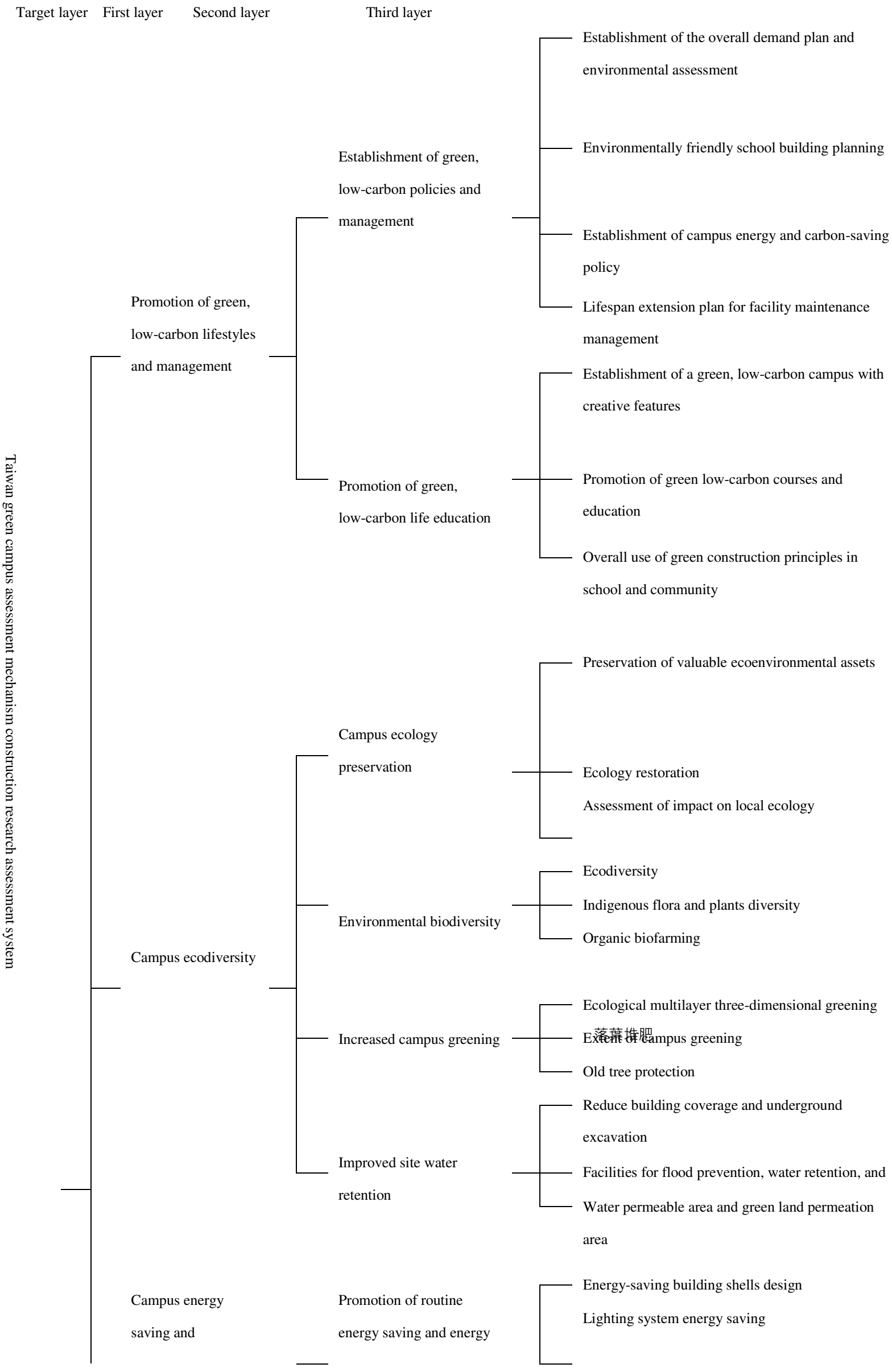




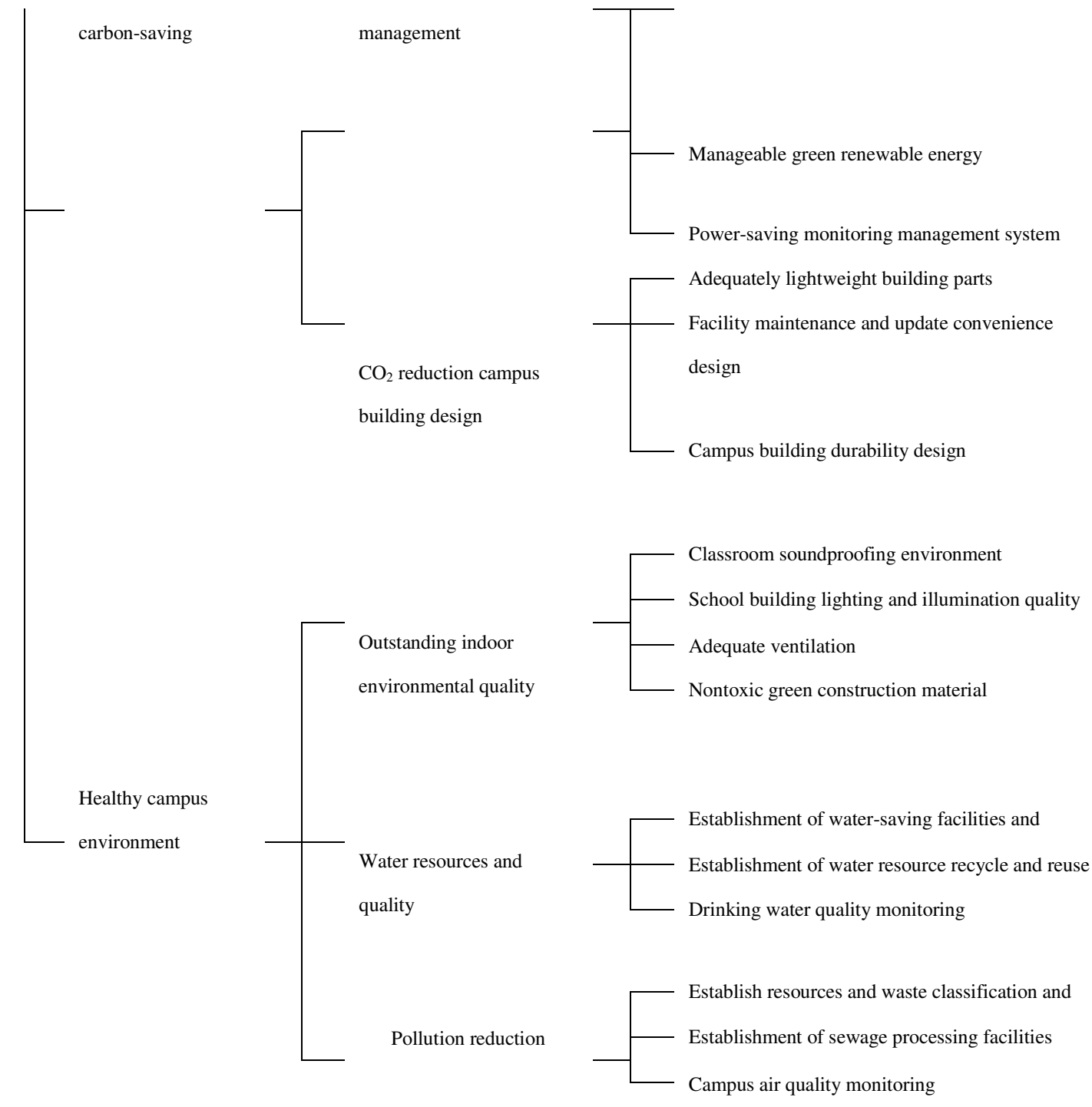

Figure 1. Research assessment layer system of the Taiwan green campus assessment mechanism.

On the basis of the aforementioned AHP statistical results for academic researchers, government experts, and all decision-makers, we conducted difference analysis on the weight and importance of each assessment factor and layer. The findings were as follows:

1. Difference analysis for first layer of assessment aspects

2. In the difference analysis for the items in the first layer of assessment aspect, academic research, government, and all decision-making experts ranked the promotion of green, low-carbon lifestyles and management first in importance, indicating that in the Taiwan green campus assessment mechanism construction research assessment, all experts emphasized the layer representing the promotion of green, low-carbon lifestyles and management with the intention that green, low-carbon policies and management as well as green, low-carbon lifestyles and education would increase green and environmental awareness among teachers and students on campus, subsequently enhancing carbon reduction and energy saving on campuses.Difference analysis for factors in the third layer of assessment

For the third-layer assessment factors, relevant analysis was based on the top five rankings for importance by the academic researchers, government experts, and all decision-makers as well as on overall assessment factor difference analysis (Table 5). The top five assessment factors ranked by academic researchers were, in descending order, overall use of green construction principles in the school and the community, energy-saving building shell design, establishment of a green, low-carbon campuses with creative features, promotion of green low-carbon courses and education, 
and energy-saving lighting equipment and systems. The top five assessment factors ranked by government experts were, in descending order, overall use of green construction principles in of the school and the community, establishment of the overall demand plan and environmental assessment, lifespan extension plans for facility maintenance management, establishment of a green, low-carbon campus with creative features, and adequate ventilation. The top five assessment factors ranked by all decision-makers were, in descending order, overall use of green construction principles in the school and the community, establishment of a green, low-carbon campuses with creative features, energy-saving building shell design, and establishment of the overall demand plan and environment assessment. In short, based on the top five importance ranking analysis, academic experts prioritized lifestyles, learning, management, and healthy environments for establishing green, low-carbon schools. The government emphasized green, low-carbon lifestyle education and management and energy-saving planning, and all experts stressed promotion of green, low-carbon lifestyle education and management and campus energy-saving planning by schools. In addition, all three parties ranked the overall use of green construction principles in the school and the community first in importance, showing that, in the Taiwan green campus assessment mechanism construction research assessment factors, this aspect was emphasized under the premise that, through collaboration between communities and schools and through green-resource sharing, sustainable communities may be created that grow and develop alongside schools.

Table 5. Differences in level-three assessment factor rankings of expert groups.

\begin{tabular}{|c|c|c|c|c|c|c|}
\hline \multirow[t]{2}{*}{ Level-three Assessment Factor } & \multicolumn{2}{|c|}{ All } & \multicolumn{2}{|c|}{ Government } & \multicolumn{2}{|c|}{ Academic } \\
\hline & $\begin{array}{c}\text { Absol } \\
\text { ute }\end{array}$ & $\begin{array}{c}\text { Ranki } \\
\text { ng }\end{array}$ & $\begin{array}{c}\text { Absol } \\
\text { ute }\end{array}$ & $\begin{array}{c}\text { Ranki } \\
\text { ng }\end{array}$ & $\begin{array}{c}\text { Absol } \\
\text { ute }\end{array}$ & $\begin{array}{c}\text { Ranki } \\
\text { ng }\end{array}$ \\
\hline Establishment of overall demand plan and environmental & 0.0520 & 5 & 0.0395 & 7 & 0.0674 & 2 \\
\hline Campus energy-saving and management policy & 0.0343 & 10 & 0.0300 & 11 & 0.0371 & 9 \\
\hline Lifespan extension plan for facility maintenance & 0.0444 & 7 & 0.0333 & 8 & 0.0580 & 3 \\
\hline Environmentally friendly school building planning & 0.0176 & 22 & 0.0133 & 26 & 0.0227 & 16 \\
\hline Establishment of a green, low-carbon campus with creative & 0.0578 & 2 & 0.0610 & 3 & 0.0527 & 4 \\
\hline Overall use of green construction principles in the school & 0.1265 & 1 & 0.1391 & 1 & 0.1106 & 1 \\
\hline Promotion of green low-carbon courses and education & 0.0437 & 8 & 0.0588 & 4 & 0.0291 & 11 \\
\hline Maintenance of favorable campus ecology and restriction of & 0.0281 & 11 & 0.0250 & 14 & 0.0317 & 10 \\
\hline Repair of ecoenvironmental damage & 0.0101 & 33 & 0.0116 & 31 & 0.0079 & 34 \\
\hline Assessment of the impact of development on local ecology & 0.0117 & 31 & 0.0091 & 32 & 0.0150 & 28 \\
\hline Ecodiversity & 0.0141 & 29 & 0.0073 & 35 & 0.0249 & 14 \\
\hline Indigenous flora and plant diversity & 0.0193 & 19 & 0.0180 & 21 & 0.0197 & 22 \\
\hline Organic biofarming & 0.0077 & 36 & 0.0078 & 34 & 0.0068 & 35 \\
\hline Ecological multilayer three-dimensional greening & 0.0127 & 30 & 0.0147 & 24 & 0.0098 & 33 \\
\hline Extent of campus greening & 0.0274 & 12 & 0.0322 & 10 & 0.0206 & 20 \\
\hline Old tree protection & 0.0161 & 27 & 0.0181 & 20 & 0.0129 & 29 \\
\hline Reduction of building coverage underground excavation & 0.0100 & 34 & 0.0063 & 36 & 0.0155 & 27 \\
\hline Facilities for flood prevention, water retention, and water & 0.0109 & 32 & 0.0088 & 33 & 0.0126 & 30 \\
\hline Water permeable area & 0.0197 & 17 & 0.0135 & 25 & 0.0279 & 13 \\
\hline Energy-saving building shell design & 0.0576 & 3 & 0.0686 & 2 & 0.0444 & 8 \\
\hline Energy-saving lighting equipment and system & 0.0522 & 4 & 0.0562 & 5 & 0.0455 & 7 \\
\hline Manageable green renewable energy & 0.0159 & 28 & 0.0130 & 27 & 0.0176 & 24 \\
\hline Power-saving monitoring management system & 0.0214 & 16 & 0.0243 & 15 & 0.0177 & 23 \\
\hline Adequately lightweight building materials & 0.0090 & 35 & 0.0151 & 23 & 0.0042 & 36 \\
\hline Convenient design for building facilities maintenance & 0.0178 & 21 & 0.0236 & 16 & 0.0114 & 31 \\
\hline
\end{tabular}




\begin{tabular}{lcccccc}
\hline Durable building design & 0.0186 & 20 & 0.0277 & 12 & 0.0105 & 32 \\
Soundproof classroom environment & 0.0167 & 23 & 0.0170 & 22 & 0.0158 & 25 \\
School building lighting and illumination quality & 0.0457 & 6 & 0.0438 & 6 & 0.0474 & 6 \\
Adequate ventilation & 0.0401 & 9 & 0.0330 & 9 & 0.0493 & 5 \\
Nontoxic green construction material & 0.0164 & 25 & 0.0124 & 29 & 0.0219 & 17 \\
Establishment of water-saving facilities and water-saving & 0.0242 & 13 & 0.0205 & 19 & 0.0289 & 12 \\
Establishment of water resource recycle and reuse facilities & 0.0163 & 26 & 0.0124 & 30 & 0.0217 & 18 \\
Drinking water quality monitoring & 0.0236 & 15 & 0.0233 & 17 & 0.0232 & 15 \\
Establishment of resources and waste classification and & 0.0242 & 13 & 0.0264 & 13 & 0.0213 & 19 \\
Establishment of sewage processing facilities & 0.0166 & 24 & 0.0126 & 28 & 0.0205 & 21 \\
Campus air quality monitoring & 0.0196 & 18 & 0.0229 & 18 & 0.0157 & 26 \\
\hline
\end{tabular}

\section{Results}

Discourse on topics related to sustainability and trends for low-carbon building development are currently prominent. Junior high schools and elementary schools were therefore adopted as research objects to discuss how green building environments might be established on school campus, energy-saving and low-carbon measures be used to improve campus facilities, and teachers and students be guided regarding low-carbon lifestyles. Subsequently, families, communities, and society in general are influenced to promote participation in energy saving and carbon reduction, constructing an outstanding green, low-carbon campus and improving the overall environment. In this study, a literature review was first performed to preliminarily identify relevant assessment factors and a layer system framework. Subsequently, Fuzzy Delphi method expert questionnaire was used to collect expert opinions in the industry, government, academia, and schools to finalize the assessment factors and the layer system framework. Finally, an AHP expert questionnaire was used to collect expert opinions from various fields of the government and industry to obtain the relevant priority weight of relevant assessment factors and layer system indicators as well as to compare and analyze the opinions of experts in various fields. Subsequently, an assessment system was established for sustainable factors in research on the construction of Taiwan green campus assessment mechanisms. This informs competent government authorities in understanding and establishing suitable policies, establishing priorities for schools promoting the implementation of green, low-carbon campus application assessment and the indicator weights. It also provides a reference for architects in planning and application and for schools in promoting and implementing assessment and relevant research, thereby achieving reasonable allocation of education resources, effectively improving campus green building quality and increasing benefits in energy and carbon saving. The aforementioned research design procedure yielded the following conclusions as a reference for future green, low-carbon campus planning and design and for relevant research on obtaining energy and carbon-saving benefits.

\section{Conclusion}

\section{Energy Saving and Campus Ecology are not Decision-making Priorities for Green, Low-carbon Campuses}

The promotion of green, low-carbon lifestyles and campus management were assigned the highest relative weight (0.3762), followed by healthy campus environments $(0.2435)$, campus energy saving and carbon saving (0.1925), and campus ecodiversity (0.1878). These findings showed that, for all experts, the most highly prioritized decision in the decision sequence for constructing a green, low-carbon campus in junior high schools and elementary schools related to lifestyle education and policy management, with healthy environment assigned second place. Energy- and carbon-saving planning and ecoenvironment were ranked lower, showing that experts believed that they were not priorities for achieving a green, low-carbon campus. 


\section{Low-carbon Campus Policy and Management and the Importance of Lifestyle and Education}

To achieve green low-carbon energy-saving benefits for schools, compared with promoting routine energy saving and energy management, the aspects of green, low-carbon policies and management and lifestyle education in schools are considered to be far more critical for the promotion of environmental awareness among teachers and students on campus. Because the third-layer assessment factor weights and importance indicators reflected all decision-making experts' study of Taiwan green campus assessment mechanism construction, during the planning stage, prior comprehensive overall demand planning and environmental assessment were emphasized. During the planning stage, through participation in the overall use of green construction principles in the school and the community, favorable school building lighting and illumination quality, school buildings with adequate ventilation, energy-saving building shells and illumination design may be incorporated to plan a low-carbon, energy-saving school building environment. In the usage stage, school energy-saving and management policies and facility maintenance management were established to extend the lives of buildings and facilities to increase economic benefits. Regarding education, the promotion of green low-carbon courses and education was integrated with strategies for environmental education course activities on campus; teaching included green campus buildings, ecocampuses, and energy saving and carbon saving. Through promotions and training, the campus becomes greener, with more prominent local characteristics and greater use of creative planning.

\section{Difference Analysis for Expert Groups on the Promotion of Green, Low-carbon Lifestyles and Management}

The assessment aspect relating to the promotion of green, low-carbon lifestyles and management was allocated the highest weight and top ranking by all expert groups (including all decision-makers, government experts, and academic experts), showing that, in the Taiwan green campus assessment mechanism construction research assessment, expert groups highly consistently emphasized green, low-carbon policies and management, lifestyles, and education at schools to improve the environmental protection awareness among teachers and students to facilitate low-carbon and energy-saving benefits on campuses. However, the aspect of campus energy- and carbon-saving planning was ranked fourth by government experts and assigned a weight of 0.1513 , whereas the academics ranked it second and assigned it a weight of 0.2243 , which was a $0.0730(7.3 \%)$ difference from that assigned by the government. This difference showed that, in relation to campus energy- and carbon-saving planning, academia and the government had different views regarding the assessment of energy-saving facilities, the use of high-efficiency facilities, the use of green renewable energy, and management to achieve campus energy-saving and carbon-reduction benefits. Difference analysis on the weights and rankings for the critical points in the second assessment further revealed that all expert groups-decision-makers, government experts, and academic experts-assigned the highest absolute weight and first ranking to the establishment of green, low-carbon policies and management, showing that, among the major points in the Taiwan green campus assessment mechanism construction research assessment, experts mostly emphasized green, low-carbon policies and management for schools to increase the benefits of low-carbon energy saving on campus. Their views on this were highly consistent. However, the weight value assessed by academics was 0.2589 , whereas that by the government was 0.1924 , showing that, compared with the government experts, academics placed more value on the promotion of green, low-carbon lifestyle education. The weight difference was 0.0665 (6.55\%), which is rather large. Moreover, for the Critical assessment points regarding establishment of green, low-carbon policies and management, the rankings from the government and the academic experts differed by one place; academics assessed the weight value as 0.1160 , and the government assessed it as 0.1853 , showing that the government valued this consideration more than the academics did. The weight difference was $0.0693(6.93 \%)$, which was rather large. Therefore, for assessment of the aspect representing promotion of green, low-carbon lifestyles and management, academics placed a greater emphasis 
on the promotion of green, low-carbon lifestyle education, whereas the government placed relative value on the establishment of green, low-carbon policies and management, indicating a major difference between the focuses of the two groups.

\section{Green Overall Construction Design Thinking in Schools and Communities}

From the difference analysis of third-layer assessment factor weights and rankings and from the top five priority-ranking analysis, we discovered that academics prioritized green, low-carbon lifestyle education and management and healthy environments in schools, the government prioritized green, low-carbon lifestyle education and management and energy-saving planning, and all experts prioritized schools' promotion of green, low-carbon lifestyle education and management, and campus energy-saving planning. In addition, academia, the government, and all decision-makers considered that overall use of green construction principles in the school and the community had the highest weights, showing that, among the Taiwan green campus assessment mechanism construction research assessment factors, aspects representing the overall use of green principles in construction in the school and the community were emphasized by all experts in the hope that, through green resource sharing between communities and schools, sustainable communities and schools might be constructed and grow and develop together.

Overall, experts believe that campus environments generate intangible effects on learners, who form views and opinions in relation to their surroundings and are encouraged to address their ecological concerns in other contexts. In schools, the teaching and administration are related to the space itself, driving the green school plan as a whole. Therefore, the assessment of campus construction and greening aesthetics is a critical green school indicator. In short, regarding the construction of outstanding green, low-carbon campuses for junior high schools and elementary schools, campus greening, favorable energy-saving facilities, and the planning of a diverse eco-campus and a healthy environment are indispensable. However, through this study and valuable expert opinions, we discovered that the optimal method of achieving the desired campus environments is to center people, integrate environmental education topics and courses, and organize field trips, providing students with first-hand experience of the environmental situation and using courses to communicate the urgency of environmental concerns to students, establishing favorable education provision and desirable attitudes, guiding schools, teachers, and students to apply environmental-protection, energy-saving, and carbon-saving principles, thereby promoting these concepts to families, communities, and society in general.

\section{Declarations}

Ethics approval and consent to participate: Not applicable

Consent for publication: Not applicable

Availability of data and materials: The datasets generated during and/or analysed during the current study are available from the corresponding author on reasonable request.

Competing interests: The authors declare that they have no competing interests.

Funding: The authors declare that they have no known competing financial interests or personal relationships that could have appeared to influence the work reported in this paper.

Authors' contributions: Conceptualization, T.J.W. and C.Y.Z.; Methodology, T.J.W.; Formal Analysis, Preparation, T.J.W. and C.Y.Z.; Writing, Review and Editing, T.J.W. and C.Y.Z.; Visualization, C.Y.Z.; Supervision, T.J.W. and C.Y.Z.; Project Administration, T.J.W. and C.Y.Z. Acknowledgements: Not applicable 


\section{References}

1. Tang, C.M. New Perspective of Campus Planning; WuNan Publisher: Taipei, Taiwan, 2014.

2. Ghent, C.; Trauth-Nare, A.; Dell, K.; Haines, S. The influence of a statewide Green School Initiative on student achievement in K-12 classrooms. Appl. Environ. Educ. Commun. 2014, 13, 250-260.

3. Meiboudi, H.; Lahijanian, A.; Shobeiri, S.M., Jozi, S.A.; Azizinezhad, R. Development of a new rating system for existing green schools in Iran. J. Clean. Prod. 2018, 188, 136-143.

4. Wang, J.C. A study on the energy performance of school buildings in Taiwan. Energy Build. 2016, 133, 810-822.

5. Kibert, C.J. Sustainable Construction: Green Building Design and Delivery; New York: John Wiley \& Sons, 2012.

6. Shih, Y.; Liu, K.; Chiang, C.; Chen, N. Discussions on practice and effect of transforming idle spaces with energy-resource techniques in Taiwanese schools-Using elementary/secondary schools as an example. Energy Build. 2014, 68, 660-670.

7. AASHE. Sustainable campus index. Available online:

8. https://www.aashe.org/wp-content/uploads/2019/08/SCI-2019-Updated.pdf (accessed on May 22, 2019).

9. Yeh, S.C., Huang, J.Y.; Yu, H.C. Analysis of energy literacy and misconceptions of junior high students in Taiwan. Sustainability 2017, 9, 423.

10. Savelyeva, T.; Park, J. Complexity of campus sustainability discourse. In Sustainable Development at Universities: New Horizons; Filho, W.L., Ed.; Oxford, Peter Lang Scientific Publishers: Frankfurt, USA, 2012; pp. 183-192.

11. Luo, X.; Ma, C.; Ge, J. Evaluation model and strategy for selecting carbon reduction technology for campus buildings in primary and middle schools in the Yangtze River Delta Region, China. Sustainability 2020, 12, 534.

12. Ramli, N.H.; Masri, M.H.; Zafrullah, M.; Taib, H.M.; Hamid, N.A. A comparative study of green school guidelines. Procedia Soc. Behav. Sci. 2012, 50, 462-471.

13. Wang, J.C.; Huang, K.T.; Ko, M.Y. Using the fuzzy delphi method to study the construction needs of an elementary campus and achieve sustainability. Sustainability 2019, 11, 6852.

14. Matthew, H.E.; Browning, M.; Rigolon, A. School green space and its impact on academic performance: A systematic literature review. Int. J. Environ. Res. Publ. Health 2019, 16, 429.

15. Zhao, D.X.; Johnson, C.; Mou, B. Social problems of green buildings: From the humanistic needs to social acceptance. Renew. Sustain. Energy Rev. 2015, 51, 1594-1609.

16. Li, Z.; Chow, D.H.C.; Yao, J.; Zheng, X.; Zhao, W. The effectiveness of adding horizontal greening and vertical greening to courtyard areas of existing buildings in the hot summer cold winter region of China: A case study for Ningbo. Energy Build. 2019, 196, 227-239.

17. Huckle, J. Sustainable schools: Responding to new challenges and opportunities. Geography 2009, 94, $13-21$.

18. Łaszkiewicz, E.; Sikorska, D. Children's green walk to school: An evaluation of welfare-related disparities in the visibility of greenery among children. Environ. Sci. Policy 2020, 110, 1-13.

19. Feng, Q.; Li, Y. Green campus environmental design based on sustainable theory. J. Clean Energy Technol. 2018, 6, 159-164.

20. Chan, T.C.; Saunders, R.; Lashley, L. Green school leadership: What does it really mean? In Marketing the Green School: Form, Function, and the Future; Chan, T.; Mense, E.; Lane, K.; Richardson, M., Eds.; IGI Global: Hershey, PA, USA, 2015; pp. 232-242.

21. Huang, K.T.; Wang, J.C. Greenhouse gas emissions of tourism-based leisure farms in Taiwan. Sustainability 2015, 7, 11032-11049.

22. Chen, C.W.; Wang, J.H.; Wang, J.C.; Shen, Z.H. Developing indicators for sustainable campuses in Taiwan using fuzzy Delphi method and analytic hierarchy process. J. Clean. Prod. 2018, 193, 661-671.

23. Sanfo, J.B.M.B. A three-level hierarchical linear model analysis of the effect of school principals' factors on primary school students' learning achievements in Burkina Faso. Int. J. Educ. Res. 2020, 100, 101531.

24. Saaty, T.; Erdener, E. A new approach to performance measurement the analytic hierarchy process. Design Methods Theor. 1979, 13, 62-68.

25. Lei, J.; Huang, W. Pragmatic professionalism: A fuzzy delphi study on the competencies of social workers in Guangzhou, China. Br. J. Soc. Work 2018, 48, 505-524. 
26. Ishikawa, A.; Amagass, M.; Shiga, T.; Tomizawa, G.; Tatsuta, R.; Mieno, H. The max-min Delphi method and fuzzy Delphi method via fuzzy integration. Fuzzy Sets Syst. 1993, 55, 241-253. 
Figures

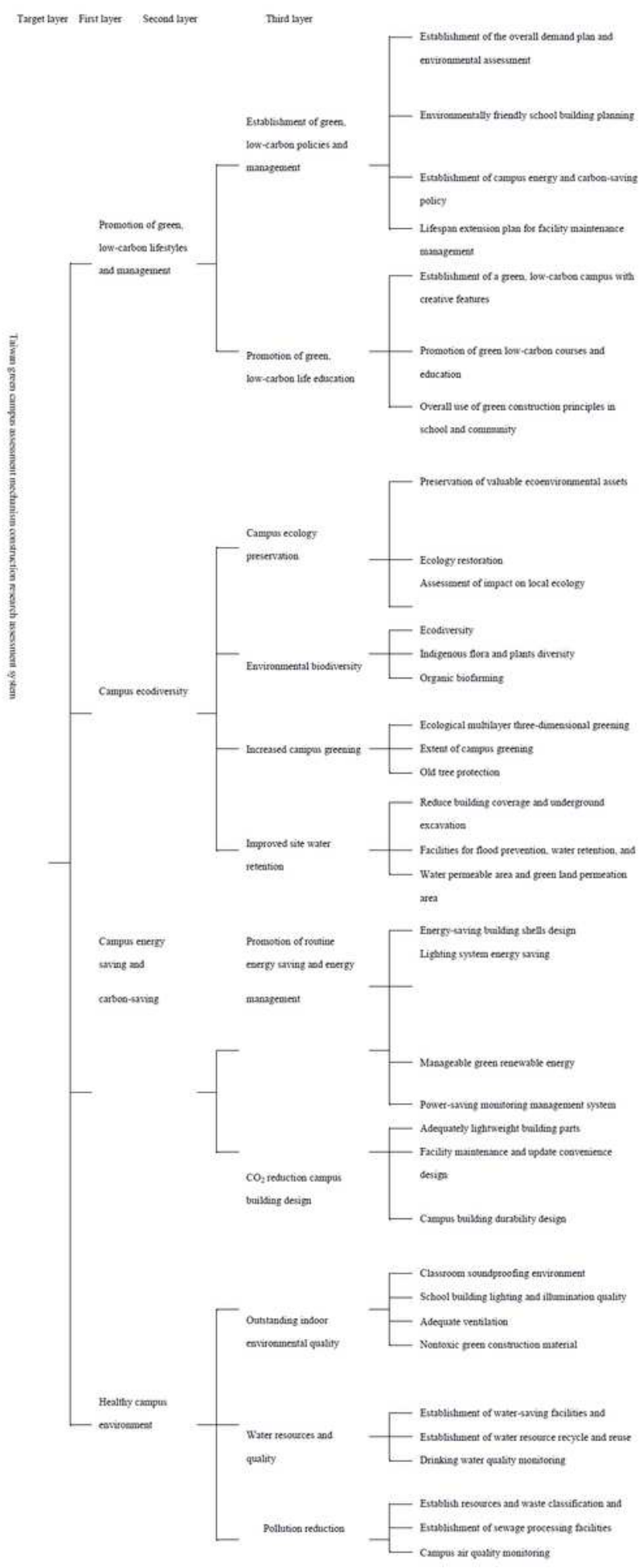

Figure 1

Research assessment layer system of the Taiwan green campus assessment mechanism.

\section{Supplementary Files}


This is a list of supplementary files associated with this preprint. Click to download.

- ESSHighlights.pdf 